\title{
Two Assemblages of Cultural Transmission: Musicians, Political Actors and Educational Techniques in the Ottoman Empire and Western Europe
}

\author{
NEDIM KARAKAYALI ${ }^{1}$
}

\begin{abstract}
In this study I aim to develop a sociological understanding of why certain techniques of cultural transmission are more easily accepted in some societies than in others. With this aim in mind, I present a comparative analysis of the contrasting approaches to music education in Western Europe and the Ottoman Empire. While, as a major technique of cultural transmission music notation found relatively widespread acceptance in Western Europe at least since the eleventh century onwards, most musicians in the Ottoman Empire resisted its adoption until the end of the nineteenth century. The analysis focuses on the ways in which the choices of Ottoman and West European musicians interacted with broader social and political processes in the two societies. In the light of this analysis, it is suggested that technologies used in cultural transmission can be seen as parts of a broader assemblage and their rejection or acceptance can be conditioned by a series of socio-political concerns.
\end{abstract}

$* * * * *$

This article stems from a broad sociological interest in the relationships between technology, culture and politics. More specifically, I aim to investigate the role of political actors in processes of technological and cultural change, focusing on a "softer" set of technological artifacts, namely, techniques and technologies used in cultural communication and reproduction. For a long time, many social scientists working in this field have underlined that sociocultural change can be triggered by the invention of new techniques of cultural transmission (Benjamin, 1968; Baudrillard, 1983; Goody, 1977). The introduction of new media of communication, it has been suggested, does not only lead to a quantitative change in the flow of information, but also changes "the type and mode of communication," which affects the routes that "sociocultural evolution" can take (Luhmann, 1995:162).

These studies contribute a great deal to our understanding of the relationship between technology and culture by showing how deeply cultural forms can be intertwined with the media which are used in their communication and replication. At the same time,

${ }^{1}$ Dr. Nedim Karakayali, Dept. of Political Science, Bilkent University, Turkey. 
however, an exclusive focus on the effects of technical media might lead to a considerable simplification of the problem at hand.

To put it bluntly, technological inventions do not fall from the sky. Even if we suppose that they do, such inventions are not put into use unconditionally; the availability of a certain technique of cultural transmission does not guarantee its widespread utilization. Technologies such as writing, printing and the Internet are not always welcome in the same manner in different societies and, historically, there has been a wide range of responses to the adoption of new methods of cultural reproduction. Yet, few sociologists, if any, have tried to carry out a systematic cross-cultural comparison of the use of communication technologies. ${ }^{1}$

This brings us to the main question that informs this study: Why is it that certain techniques of cultural reproduction and transmission are easily accepted in some societies, whereas in others there develops significant resistance to their adoption?

One immediate answer that comes to mind is that such differences follow from different cultural norms and values which constrain or encourage the use of various technologies. In this sense, it might seem highly meaningful to talk not only about "reproduction of culture," but also about different "cultures of reproduction" - which might be defined as the norms, beliefs and theories about how knowledge, skills and cultural repertories are to be preserved and disseminated in a society. However, unless carefully qualified, such an answer might easily throw us in the direction of a kind of cultural determinism, which is likely to simplify the problem no less than the exclusive emphasis on technical media does.

Strictly speaking, there is nothing "wrong" with either of the propositions I considered above: technical media can influence cultural forms; cultural norms might influence the practices of cultural transmission. These "influences," however, do not take place in a vacuum; they require the participation of concrete social and political actors, who, for various reasons, support or refuse the use of a technique, or try to preserve or transform certain cultural norms. It is precisely these intricate networks consisting of multiple actors which are missing from the pictures provided by approaches that emphasize either technical media or cultural norms. What I propose to do in this study, therefore, is to investigate the actual, historically specific networks and assemblages in which the invention, utilization or rejection of a technique of cultural transmission occurs. I will refer to these assemblages as assemblages of cultural transmission. ${ }^{2}$

In this study, I present a historical comparison of two "assemblages of cultural transmission" in the specific domain of music, focusing on the contrasting approaches of Ottoman and Western 
European musicians to music notation and education. The fact that, for a very long time, music notation did not find any widespread use among Ottoman art $^{3}$ musicians is documented and discussed in many musicological studies (Behar, 1987; Feldman, 1996; Ayangil, 2008; Popescu-Judetz, 1996). There is also a substantial literature on the gradual transition from oral transmission to notated music in Western Europe (Parrish, 1957; Cattin, 1984; Jeffery, 1992; Boynton, 2003; Bent et al., 2009; Atkinson, 2009). So far, however, there has been no attempt to combine the findings in these two bodies of literature. Nor is there any comparative sociological analysis of why and how methods of transmission and education in these two music traditions diverged from each other in such significant ways. The present study builds on the existing literature to carry out such an analysis. ${ }^{4}$

More specifically, I try to highlight the fact that the rejection or acceptance of notation as a technique is linked to a series of social, political and cultural developments that go far beyond the practical concerns of musicians. ${ }^{5}$ Here, I pay special attention to what might be called the "politics of music notation," taking my starting point in the rather vast literature on the socio-political significance of technologies used in cultural transmission. ${ }^{6}$ The most important insight I draw from these studies is that since techniques of reproduction are deeply intertwined with standardization of cultural practices as well as distribution of cultural capital and information, they often function as political technologies. I argue that, partly because music had a very different place in collective rituals and religious institutions in Ottoman and European societies, musicians and political/religious authorities in each society had very different incentives (and institutional capabilities) to control musical repertories and education. In other words, the nexus of political actors, musicians, and techniques of musical transmission was assembled differently in each society.

In what follows, I will first outline the different attitudes of musicians and theorists towards music education in Ottoman and European societies. I will then turn to the broader historical context to explore the role of other social and political actors in the emergence of these differences. ${ }^{7}$

\section{I - Two Ways of Teaching Music: Ottoman Art Musicians and Guido d'Arezzo ${ }^{8}$}

How did Ottoman Musicians Teach Music?

Besides the widespread use of written documents in state administration, Ottomans had a well-established tradition of history 
writing and institutions of higher education (Caksu, 2001). Ottoman art musicians performed and composed their music in the context of this script culture. Many of them were well-educated and literate. Indeed, several notation systems were available to these musicians, had they wished to adopt them. ${ }^{9}$ Yet, with a few exceptions, art musicians did not prefer to use writing as a main technique of musical transmission and music notation did not find any widespread use among them up until the end of nineteenth century, if not later (Behar, 1987:19; Feldman, 1992; Ayangil, 2008).

This does not necessarily mean that Ottoman musicians always reacted to notation in a uniform manner. There was, first of all, a small minority of native musicians, both Muslims and nonMuslims, who devised and experimented with indigenous notation systems and used them in their collections and theoretical treatises, although their endeavor does not seem to have left any significant marks in the larger community of musicians. ${ }^{10}$ Also, when Ottoman musicians encountered music notation through foreigners who worked as musicians at the Ottoman court, their attitude was rather positive. Such was the case with Bobowski/Ali Ufki (see footnote 9), whose "craft" was appreciated by other musicians at the Court. Indeed, Ali Ufki noted in his memoirs that some of the younger musicians asked him to teach them notation, though he refused this request thinking that this could delay his departure from Istanbul (Behar, 1990:45). Similarly, Cantemir writes that his notated collection was praised by Ottoman musicians (see: Popescu-Judetz, p.25). ${ }^{11}$

These examples indicate that Ottoman musicians did not simply have a generalized negative attitude towards notation. Nevertheless, most of the well-established master musicians seemed to have little or no interest in using notation either in their teaching practices or in recording their compositions. In fact, in some cases, their attitude could be quite harsh. Thus, a master musician of nineteenth century, Bolahenk Nuri Bey is known to have reproached his student Melekzet Efendi, when the latter, unbeknownst to the master, wrote down a composition that they were rehearsing during a teaching session. When, at the end of the session, the student recited the whole composition from the written notes, the master became furious, accusing the student with "snatching" in a few minutes a composition that cost the master himself a month's labor (Behar, 1987:45-6).

To make a better sense of the unwillingness of master musicians to adopt notation as a method of teaching, we need to look closer to the practices of Ottoman musicians. The basic method of music education in Ottoman art music was meşk (pronounced as meshk), 
which can roughly be translated as "practice." And, definitely, meşk was first of all a technique of cultural transmission based on imitation and memorization, originally developed by calligraphic artists. In the case of calligraphy, interested students would find a master who would instruct them "letter by letter" and "[t]he imitation of models written by these masters was an important part of instruction" (Schimmel, 1990:37; see also: Behar, 1998). The same principles were also adopted by musicians. In many ways, meşk resembles the mnemonic techniques used in other oral music traditions including early medieval European music (Boynton, 2003:108; Busse-Berger, 2005; Rubin, 1995; Treitler, 1974).

However, we should not interpret meşk merely as a mnemonic technique, since it also involved - probably as in all music education prior to musical notation and, to a large extent, still today - a direct musical intercourse between a master and a student. What Schimmel (1990:14) notes about calligraphy education was also true for music: "[t]he relation between master and disciple was, in a certain sense, similar to the close, loving relationship between a Sufi pir (spiritual guide) and his murid (disciple)."

As Behar $(1987,1998)$ has shown in several of his works - which are, so far, the most detailed studies on Ottoman music education - meşk sessions sometimes lasted for a lifetime. During these sessions, in addition to musical knowledge and skills, a whole range of socio-cultural codes were passed on to a new generation of musicians. Meşk can therefore be understood as a semi-ritualistic activity by which the apprentice is introduced to a particular habitus - i.e. to "a system of schemata of perception and appreciation of practices, cognitive and evaluative structures" which can only be acquired through "lasting experience" (Bourdieu, 1990: 131).

The crucial point for our concerns here is that meşk is not simply a means to a particular end. It is not an "instrument" that aids the passing of the elements of a tradition to new generations; it is the tradition (Behar, 1998:11). In a sense, meşk has no end and it never comes to an end. At a given point in his life, an Ottoman musician is either in the process of "receiving messk" or "giving messk" (or both) - the latter is seen as a kind of obligation of a master musician who has to "pay back" the messk s/he has received from others without any fee. ${ }^{12}$ Given the voluntary and "gratis" nature of these transactions, we can talk about a "messkcycle," which in most details resembles the "gift-cycle" described by Marcel Mauss (1954).

We might then begin to understand why music notation - which renders the long, ritualistic interaction between a master and a student redundant, and which is potentially capable of turning 
musical education into an "instrumental" process - can be conceived as incommensurable with the values of Ottoman musicians. As we shall see later, however, this is only part of the picture. I will elaborate further on this point in Section II.

Music Education in Medieval Western Europe and the Birth of Staff Notation

Although music historians are far from fully re-constructing the methods of teaching in medieval Western Europe, most of them tend to agree that during the period from the fifth to the eighth century, written texts without notation were used by monks to conduct and teach religious chants, and the melodies sang to these texts were transmitted orally (Jeffery, 1992:10; see also: Boynton, 2003; Busse-Berger, 2005; Treitler, 1974). Existing documents indicate that, from the ninth century onwards, various primitive, neumatic notation systems were developed in monasteries in different regions of Europe (Jeffery, 1992:6). It is quite likely that, as in many other oral cultures, these early forms of notation were invented as mnemonic devices in a predominantly oral context.

Modern European music notation, however, did not evolve naturally out of these mnemonic devices. The refinement of notational systems, all from the beginning, owed a great deal to the "interventions" of music theorists. It is important to note here that long before the emergence of neumatic notation in the ninth century, scholars writing on music theory were making use of various forms of visual representations such as diagrams, tablature signs, "letter notes," and so on. This was, for example, the case in the treatises of Boethius, who was probably the most widely read music theorist in the Middle Ages. Boethius' aim, however, was not to devise a "practical notation" to represent actually existing music in his time; his diagrams and symbols were created with the aim of illustrating the logical and mathematical principles of music theory. This is, in fact, quite similar to the attempts of certain scholars in medieval Islamic societies who utilized a phonetic notation in their theoretical works (Farmer, 1970; Popescu-Judetz, 1996). ${ }^{13}$

However, in the ninth century, at the dawn of the Carolingian era, a gradual transformation in the utilization of notation in treatises on music theory would take place in Europe. As Atkinson (2009) shows, although the authors of the treatises written in the ninth and tenth centuries were still concerned with conceptual and theoretical problems, in comparison to their predecessors, they seemed to be much more inclined to use and develop 
notation for practical purposes such as teaching, recording and classifying the existing repertories. This change was already visible in the works of well-known ninth century music theorists such as Aurelian and Hucbald, whose works can be characterized as practical manuals for singers of church music (Atkinson, 2009:114-150). It might therefore be argued that for these music theorists and their successors, notation was not just a theoretical tool for "reflection" but also a practical technology of cultural transmission and preservation.

As we shall see later, it was not a coincidence that this interest in "practical notation" emerged in the Carolingian age. But it was certainly not a temporary development unique to this era. In fact, probably the most paradigmatic, though by no means the only, example of this transformation can be seen in the work of the eleventh century music theorist Guido d'Arezzo. Like many of his predecessors in the ninth and tenth centuries, in his famous work Micrologus, Guido used a letter notation both for theoretical purposes and for notating chants. But in a later work, Prologus in Antiphonarium, he took a step further, combining the "line diagrams" used for theoretical purposes with the "traditional" neumes which were devised for practical purposes but which could not be used to indicate exact pitch (Atkinson, 2009:228).

The result of this marriage between "theory" and "practice" was a highly refined form of "staff notation" which, as almost all historians of music would agree, had the potential of enhancing the practice of sight-singing considerably. ${ }^{14}$ In creating this new notation, Guido's major aim was to improve the skills of music students. More importantly, he was hoping that his system would allow students to learn new songs directly from notation with little help from a senior musician: “. . . I have decided, with God's help, to write this antiphoner so that hereafter, by means of it, any intelligent and studious person may learn singing and so that, after he has thoroughly learned a part of it through a master, he will unhesitatingly understand the rest of it by himself without one" (Guido of Arezzo, 1965:118; see also: Atkinson, 2009:229; Cattin, 1984; Sinding-Larsen, 1991:107).

Some scholars claim that Guido's "system changed the whole relationship between writing and music in the greater part of Europe in a remarkably short space of time" (Bent et al., 2009). This, of course, does not mean that Guido revolutionized music education at one stroke, bringing an end to oral transmission once and for all. The potential of Guido's system was not fully realized for a long time. Busse-Berger (2005:50), for example, argues that initially staff notation was not so much used in learning new pieces; rather it "would help singers in performances of pieces they already 
knew" and "the basic techniques for memorizing and retrieving the pieces remained similar [i.e. based on an oral tradition] from ca. 800 to 1500." ${ }^{15}$ But the important point is that staff notation eventually spread throughout Europe and became an integral element in all domains of musical activity. The idea of notating music would become so internalized in European thought that, a few centuries later, when European travelers visited Istanbul, one of the first things they were going to notice about Ottoman music would be the absence of notation (Aksoy, 1994).

\section{Meşk and Notation as Aspects of Two Different Philosophies of} Music Education

It might have already been noticed that the notation system refined by Guido d'Arezzo and developed further by his successors can be contrasted with the meşk tradition of Ottoman musicians in terms of the underlying value orientations regarding how musical education should be carried out. Above all, these two traditions evaluate, i.) the interrelationship between the student and the teacher, and ii.) the time and toil spend in musical transmission in diametrically opposite ways. Let me briefly clarify these points.

i-) Personal, context-dependent transmission versus "learning songs that one has never heard": In the messk tradition of Ottomans, reproduction means re-producing the "original" work performed by a master musician by imitating him/her as diligently as possible. Furthermore, as Behar (1998: 33, 97-101) notes, ultimately the identity of an "art" musician in the Ottoman society was inextricably linked to the masters from whom s/he received messk, and the students to whom $\mathrm{s} /$ he gave messk - a tradition which encompasses also arts such as calligraphy, as well as the training of Sufi apprentices, where "a silsila, a spiritual chain, was absolutely necessary to connect the discipline [sic.] through generations of masters with the founder" (Schimmel, 1990:37). ${ }^{16}$

In contrast, the notation system developed by Guido d'Arezzo has the potential of significantly reducing the dependence of the process of reproduction on local contexts. Even if implicitly, it devalues the personal and direct link between a teacher and a student. In Prologus in Antiphonarium, Guido openly laments the fact that musicians are far too dependent on their teachers:

In our times, of all men, singers are the most foolish. For in any art those things which we know of ourselves are much more numerous than those which we learn from a master. ... But marvelous singers, and singers' pupils, though they sing every day for a hundred years, will never sing one antiphon, not even a short one, of themselves, without a master, losing time enough in singing to have learned thoroughly both sacred and secular letters. (Guido of Arezzo, 1965:117). 
Indeed, Guido was proud of his invention especially because it was capable of making the student learn new songs without the aid of a teacher (Cattin, 1984, p.176-7). It seems then that, for Guido, one primary function of notation was that it facilitated indirect, individual learning of musical compositions. ${ }^{17}$

ii-) The ritualized learning process where time and toil are praised versus the de-ritualized and efficient cultural transmission: As a whole, meşk can be seen as the founding moment of a social ritualization, which is not only essential for the continuation of established practices, but which also allows the gradual assimilation (or "naturalization") of various innovations - e.g. a new composition by a master, or, even a new technique for articulating a particular musical phrase - into a tradition. More specifically, as I have briefly noted above, meşk can be seen as an integral part of a habitus which is built up and sustained through repetition and lasting experience. I cannot stress more the ritualistic and performative nature of this repetitive experience: meşk sessions are not merely about the training of auditory and tactile senses of a musical apprentice; ${ }^{18}$ the "habits" and "memory" engendered as a result of these repetitive sessions encompass many activities ranging from proper manners of sitting and expressing emotions, to the ways of listening, playing and appreciating music.

One potential consequence of the advent of music notation is the elimination of precisely this ritualistic dimension from music education, through the reduction of the duration and frequency of encounters between masters and students. In fact, as he puts it in a letter where he evaluates his invention, such a reduction seems to be one of Guido's major aims: "the ecclesiastical songs which I and all those before me learned with the greatest difficulty may be learnt with the greatest ease by men to come" (cited in Cattin, 1984:176). In this respect, Max Weber (1958) seems to be justified in suggesting that the utilization of notation contributes to the "rationalization" of Western music. It might even be argued that one major consequence of Guido's system was the "disenchantment" of music education since it facilitates the elimination of repetitive, ritualistic elements from educational practices.

As such, Guido d'Arezzo's attitude is diametrically opposed to the above mentioned attitude of Bolahenk Nuri Bey, who praised the time and toil involved in musical apprenticeship. The Ottoman master's resistance to the "efficiency" brought about by music notation, which he interprets as "snatching," stems from the almost super-human quality he (and many others) attribute to time and toil spent in mastering an art. As one famous calligraphy master, Mir-Ali Tabrizi (15th c.), puts it: 
Forty years of my life were spent in calligraphy;

The tip of calligraphy's tresses did not easily come in my hand.

If one sits leisurely for a moment without practicing,

Calligraphy goes from his hand like the color of henna. (cited in Schimmel, 1990:38).

This, of course, does not mean that meşk was merely a painful activity which involved no joyful experience. However, the important point is that the sacrifices and efforts of the student engaged in meşk are by no means viewed as a negative condition. On the contrary, the presence of such efforts is what leads to the perception of musicianship - as well as the mastery of many other arts as being an extra-ordinary feat.

Bolahenk Nuri Bey's and Guido d'Arezzo's attitudes are quite representative of the dominant approaches to cultural transmission in their corresponding cultural contexts. Bolahenk Nuri Bey's attitude is common among art musicians, as well as among the practitioners of other traditional arts such as calligraphy. More generally, it is in tune with the norms of spiritual education in Sufi circles. Similarly, Guido's attempt to introduce efficient methods of teaching can be seen as an extension of the educational reforms that started in the Carolingian era (more on this point in the next section).

But can we explain the contrasting attitudes towards music education by looking at the "values" and "habits" of music educators only? It might well be that these values played a significant role in motivating musicians to accept or resist notation. But the question is what kind of forces allowed the selection, survival and dominance of these divergent sets of values in the two societies. After all, we have no reason to assume that alternative attitudes (e.g. pronotation attitudes in the Ottoman society and anti-notation attitudes in Europe) were entirely missing. Guido himself came under attack by his fellow monks because of his "radical" views on music theory and notation (Cattin, 1984:175), and even Bolahenk Nuri Bey was not always opposed to notation as he allowed some students in his circle to notate the compositions after a meşk session (Inal, 1955:82). As we will try to show in the next section, in understanding the gradual crystallization of the two opposite tendencies among Ottoman and European musicians, we should also take into consideration the different relations that were formed between musicians and other social and political actors in the two societies.

\section{II - The Politics of Music Notation and Assemblages of Cultural Transmission}

It is a well-known fact that Guido d'Arezzo's notation system was met with a positive response by some of the religious authorities of 
his time. In 1030, he was invited to Rome by Pope John XIX who was immensely pleased with Guido's achievement (Cattin, 1984; Rockstro, 1889). This positive response can only become intelligible in light of the specific social and political developments in his time, which we will briefly outline in the following. I am aware that this outline might appear to the expert scholars of medieval history somewhat superficial, since, given the space limitations, a number of facts that are not directly related to the main questions of the paper were left out. Wherever possible, therefore, I tried to refer the reader to the broader literature.

To begin with, it is quite notable that Guido's system was embraced not simply by musicians but by the highest religiouspolitical authority in his time. Pope John XIX's pontificate is considered as foreshadowing the papal reforms of the eleventh century, one major dimension of which was that the papacy began to view itself as a "global" actor. As Cowdrey (1998:10) puts it, "[t]he liturgical life of the Roman church must be kept in view if the mind and work of an eleventh-century pope are to be understood" - it is in this period that the Roman Church "proclaimed itself to the world as the head, mother, and mistress of all other churches."

These developments in the eleventh century cannot be isolated from the long history of the Roman Church, which constituted the most important power centre in Western Europe for centuries. It functioned as one of the main agents in the political and cultural unification of Western Europe, at times in cooperation and at times in competition with earthly powers, i.e. the kings and the nobility. Such an ambitious project of political unification was dependent on the standardization of a wide range of social practices. In this respect, the standardization of religious practices, especially the organization of monastic life and liturgy, had a primordial importance. This process, however, was anything but smooth. The relative autonomy of local churches which led to local versions of liturgy was one obstacle. The competition from kings and local aristocrats was another. The latter was particularly true with respect to the control of monasteries: "Throughout the Middle Ages . . . ecclesiastical and secular authorities jostled for influence, if not control, over monasteries and their resources" (Nelson, 2007:582; see also: McKitterick, 2008:297-298). The intricacies and enormous complexity of "monastic politics" is beyond the scope of our discussion. What is crucial for our purposes here, however, is that, as Susan Boynton (2006) demonstrates so vividly, liturgical practices in monasteries were far more than spiritual rituals. They were deeply political practices that were essential in the formation of monastic identities and in mediating a monastery's relation to other powers. 
The utilization of literacy and writing in the formation of a politically and culturally unified Europe has a long history. In this respect, a turning point in medieval history was the Carolingian era, particularly during the rule of Charlemagne. It has often been pointed out that one of Charlemagne's projects was to initiate a colossal reform in education and "cultural correction" (McKitterick, 2008; Sullivan, 1995). This "correction" project was not merely a cultural issue but carried strategic importance for Charlemagne's politics (McKitterick, 2008:294). As such, Charlemagne's cultural reforms was partly an attempt to invigorate the project of political unification of Europe initiated by the Roman Church; but it was, one might argue, also his attempt to appropriate this project by building up "a sacred adjunct to his own power as king" (McKitterick, 2008:298). Monasteries and liturgy were among his central concerns. In 789 Charlemagne decreed: "And let schools be established in which boys may learn to read. Correct carefully the Psalms, notas, ${ }^{19}$ the chant, the calendar, the grammars in each monastery and bishopric, and the catholic books" (cited in McKitterick, 2008:316). Indeed, one of Charlemagne's major ideals, as expressed indirectly through a letter written by one of his bishops, was "the promotion of the liturgy as it was sung in Charlemagne's own sacred palace" (cited in McKitterick, 2008:308-309).

Charlemagne's project to standardize liturgical music was not a new project. Since Christian liturgy is almost unthinkable without music, the standardization of music was a crucial issue all from the start. The relative autonomy of the local churches entailed that there existed several liturgies and bodies of chant between the fifth and eighth centuries (Jeffery, 1992). At the same time, however, there was a counter-pressure for forming a more uniform liturgical tradition, both in the Byzantine Empire, and in the West (Jeffery, 1992:6-7). The Carolingians, particularly Charlemagne, subscribed fully to this project of forming a standardized liturgical repertory. Many historians of medieval music today accept that what is known as "Gregorian" chants were actually compiled in the eighth century, long after the reign of Pope Gregory I, as part of an attempt to "import" Roman repertory into Frankish lands, at the expense of locally developed versions of liturgical repertories. ${ }^{20}$

As Atkinson (2009:85-7) points out, this "importation" of Roman repertory was especially difficult in the absence of a well-developed system of notation - in all likelihood, the emergence of a general interest in "practical notation" in the treatises of music theorists of the ninth century, which I discussed in the previous section, was a response to this challenge. ${ }^{21}$ The following anecdote reveals some of the difficulties that might arise in realizing such a colossal standardization without notation: 
[T]he king was so unhappy about the fact that the churches throughout the kingdom differed so much in the way they worshipped God and in the rhythms of their chanting that he asked the pope to send him monks skilled in church singing. But the Roman monks decided to plot to prevent the Franks from achieving uniformity. Charlemagne... [however] discovered that these monks had actually subverted Frankish chant and taught different ways of singing. Once discovered, two of Charlemagne's Frankish monks were then dispatched to Rome in order to learn it properly. (cited in McKitterick, 2008:344).

It would then perhaps not be a fantastic assumption to suggest that had Guido lived and developed his system two centuries earlier, Charlemagne and his successors would have been very much interested in utilizing this system. But this would be Pope John XIX's lot, whose motivation was not much different than Charlemagne's in embracing notation. Although the Carolingian era and the Frankish state did not last very long, the political and institutional reforms that were inaugurated in Charlemagne's time by no means disappeared. The Carolingian era was effectively over by the tenth century but "[t]he programme of renewal which the early Carolingian kings had promoted was now voiced by the Church independently" - one might, therefore, even think of the developments in the post-Carolingian era as "correction without the king" (Fouracre, 2007:378).

In all likelihood, in developing staff notation, Guido was not so much thinking about politics. But his concerns about the standardization of musical practices and repertory were almost identical to that of Charlemagne and other religious authorities:

... the antiphoners are not one, nor yet a few, but rather as many as are the masters in the single churches; and that the antiphoner is now commonly said to be, not Gregory's, but Leo's, or Albert's, or someone's else. . . . In which matter, since the masters change many things arbitrarily, little or no blame should attach to me if I depart from common use in scarcely more than a few respects in order that every chant may return uniformly to a common rule of art. (Guido of Arezzo, 1965:118).

So, the development of musical notation and its extensive use was in full compliance with the interests of political and religious authorities in Guido's time. In this sense, it would perhaps not be an exaggeration to suggest that notation was as much a "political technology" as it was a pedagogical device. Initially its most systematic, though most probably not the only, usage was in religious music practiced by monks. ${ }^{22}$

As I have already noted above, it took several centuries before the full potential of Guido d'Arezzo's system was realized (BusseBerger, 2005:48). Since in this study I am only interested in understanding the sociological conditions that motivated the initial acceptance of music notation, the later evolution of European 
notation is beyond the scope of this paper. Nevertheless, it is worth noting that, from the eleventh century onwards, the utilization of music notation went through significant mutations. As Cole (1974:9) summarizes, the later uses of notation include, among others, "[t]o allow the writer to invent new music, and to calculate effects in advance and at leisure ... [t]o provide an exact timetable, so that independent parts may be closely coordinated . . . [and t]o describe the sounds of performed music for purposes of analysis or study." Music notation, in other words, did not just provide an efficient means for preserving a standardized repertory; in the long run, it provided more autonomy for individual composers and, paradoxically enough, facilitated the de-centralization and diversification of musical practices in the Western world. These developments, however, were quite unforeseeable in Guido's time.

$* * *$

In the case of the Ottomans, the interrelationships between political and religious actors, and musicians were patterned in a very different way. Potentially there were three major socio-political actors that might exert an influence on musicians: religious authorities, the Court, and Sufi orders. As we will try to clarify in the following, however, none of these actors had a reason to intervene in music education in the same manner as in Western Europe - at least not until the end of the nineteenth century.

At first sight, it might seem that religious authorities would be more interested in controlling the activities of musicians than any other group. After all, in the Islamic world, music was the topic of heated debates among religious authorities and literati. As Shiloah (1995) and Shehadi (1995) show, while there is considerable diversity among scholarly perspectives, many Islamic scholars condemned music because of its association with entertainment and worldly pleasures. But since there is no explicit prohibition against music in the Koran, religious authorities, even if they wanted to, were unable to ban musical activities. Both popular and court music continued to flourish in the Islamic world. In the Ottoman Empire, "music was very much accepted, and had become an established part of dervish devotional practice, which was at times patronized by the State" (Feldman, 1990: 86). As Denny (1985) points out on the basis of his research on pictorial depictions of courtly life in Islamic societies, musicians attained a significantly high status in royal courts (see also: Feldman, 1996; Uzunçarşıll, 1977).

At the same time, however, the view of religious authorities had a lasting impact: there was no overt opposition to the idea that music should not be a recreational activity. Thus, for example, the defend- 
ers of the use of music in Sufi rituals argued that music could be an excellent tool for spiritual development (Shiloah, 1995). Similarly, court and urban musicians emphasized the spiritual dimensions of music, referring to mythological theories of "Science of Music" (Ilm el-Musiki), which allowed them to trace the origins of their activity to important historical figures, ranging from al-Farabi to Plato and even to Adam. Such legendary genealogies helped later generations of musicians to legitimize their activity and endowed them with cultural authority (Feldman, 1990: 95; Karakayali, 2001).

The Ottoman musicians' conception of their activity as serving a spiritual end was partly dictated by religious doctrines about music. Beyond this general impact on the "philosophy" of music, however, religious doctrines and authorities had little influence on the activities of musicians. This is mainly due to the fact that there is almost never music in ordinary Islamic religious practices (we shall discuss the exceptional role of music in the rituals of certain Sufi orders later). Although the recitation of the Koran involves a melodious use of the human voice, this is hardly ever perceived as "singing" in many Islamic societies. More importantly, although, as a technical term, Ottomans did recognize a genre called "mosque music" (Feldman, 1996:21-3), the performance of such music, which usually took place on a very few special occasions, was realized by a single "performer." Unlike in Christian liturgical practices and choral singing traditions of monastic life in Western Europe, therefore, "mosque music" almost never took the form of collective singing. The kind of sensitivity that the religious elites in the Ottoman Empire developed towards technologies of cultural transmission which might have a collective impact - most notably, the reaction towards the printing press (see: Ihsanoglu, 1992) - was therefore missing in the case of music education.

Another political actor which we might expect to exert some influence on musical practices was, of course, the Court. After all, the Court was the main institution that sponsored and patronized professional musicians. Whether it was of a religious or "profane" genre, however, the music performed and taught at the Ottoman Court had essentially a "recreational" purpose. It was not part of a political, collective ritual. Thus, whenever the ruling strata at the Court had any demands from the musicians, it was mostly based on personal taste about genre or style. In some extreme cases, as in the case of some Sultans who, due to their moral and religious beliefs, disapproved music, musical activities at the Court would simply be stopped. ${ }^{23}$

But even if the Court had an interest in intervening in the practice of musicians, it would most likely lack the means to succeed in this endeavor. This is because the majority of urban art 
musicians were essentially "amateurs" who did not make their living from music and who connected to each other through highly informal, local networks, which made it quite improbable that their practice could be scrutinized through a central organization. Professional musicians, who were fully under the patronage of the Court, constituted a minority (Behar, 1998). In fact, quite a few of the musicians who occasionally served for the Court had other occupations and they were hired part-time for, for example, tutoring members of "elite" households (Uzunçarş1l, 1977). Also, many musicians who served at the Court were not necessarily "graduates" of the Court's music school and were recruited due to their reputation outside the Court (Behar, 1998:44-6; Feldman, 1996:18).

Finally, some Sufi orders, particularly the Mevlevi order, constituted a third context where music occupied a much more central place than it did either in the Court or in orthodox religious ceremonies. In fact, not only the rituals but also the whole life-style and philosophy of the Mevlevis are unthinkable without music. The contribution of Mevlevi musicians and composers - many of whom also served in the Court and interacted with urban musicians without any Sufi affiliation - to Ottoman art music is widely acknowledged. As in other Sufi traditions, however, the basic norms of teaching and learning among Mevlevis underlined the importance of direct contact between a master and a student. In this respect, meşk was in full accordance with the Sufi conception of knowledge transmission where formal methods and "representations" were viewed as being at best auxiliary to direct spiritual guidance, and at worst, illusory (see, for example: Gölpınarl1, 1953; Trimingham, 1971; Behar, 1998:72; Schimmel, 1990:36-7).

It seems, then, in the absence of any sustained intervention from political and religious actors, Ottoman art musicians were free to decide about the methods and technologies they used in training new apprentices. One might nevertheless ask whether these decisions were totally devoid of a "micro-political" dimension. Could it be that, especially for the established Court and urban musicians, the preservation of the oral tradition constituted a significant advantage in terms of sustaining their social status? Since we still have very limited data to determine the sociological dynamics of the lives and careers of musicians throughout the long history of the Ottoman Empire, we can only answer this question in the form of a hypothesis.

As Ayangil (2008) notes, at least according to one of the pioneering advocates of the use of European music notation in Ottoman art music education, Notacı ("notationist") Emin Efendi, the answer to that question should be a "yes." He views the reluctance of his 
fellow musicians to use notation in their teaching practices as a self-serving strategy. In his book titled Nota Muallimi ("The Notation Teacher"), published in 1884, Emin Efendi, somewhat echoing Guido, stressed that the use of notation would make the training of new students much easier. He noted that since the prevalent method of training depended on memorization, it required very long periods of teaching. But this was precisely what the masters preferred, according to him. "[T]hey slandered the use of European notation . . . to their pupils," because they thought that the use of notation "would imperil their interests" (Ayangil, 2008:417).

But what exactly were those "interests" that the master musicians were trying to protect? We have little reason to assume that economic benefit was a major concern for Ottoman art musicians. ${ }^{24}$ A good number of urban musicians, often with Sufi affiliations, taught their lessons without any monetary return. ${ }^{25}$ Thus, at least, as far as teacher-student relations were concerned, it is quite plausible to assume that the "token" of musical "exchange" was mostly of a symbolic kind. There is almost no doubt that master musicians were treated with much respect by their students. More importantly, the absence of notation seems to have constituted a favorable condition for master musicians to remain as the main cultural actors with exclusive access to past musical accomplishments and repertory. The clash between the master musician (Bolahenk Nuri Bey) and his student (Melekzet Efendi) in the example we discussed above indicates that musical notation might give students not only easier access to "musical capital" but also considerable freedom vis-à-vis the masters, by shortening the time of learning.

In more general terms, we can hypothesize that, from a sociological point of view, what mainly motivated the musicians to strive for mastery in their art was not economic gain but the "respect" and "prestige" that this status entailed. The possibility of a musician to build up enough prestige and recognition to reach the status of a master was partly dependent on his/her individual abilities like remembering and reciting a large number of compositions (Behar, 1987:31-8). But the crucial point is that the accumulation of prestige and recognition - or, what Bourdieu (1990) would call, "symbolic capital" - was thoroughly dependent on the institution of meşk. This is so, not only because musicians built up their mastery through long and arduous messk sessions, but also because the status of a musician was dependent on the status of his/her masters and the achievements of his/her students. Any radical change in the institution of mesk, such as the introduction of notation, therefore, was likely to affect the status of master musicians. 


\section{A Test Case: When Music Gains a Political Significance in Ottoman Society}

The developments that took place in Ottoman/Turkish society since the nineteenth century are worth considering - even if briefly - since these developments show that once the relations between musicians and other social actors go through a transformation, so do the attitudes toward musical education change. Here we can talk about two separate but closely interrelated transformations, one concerning the socio-cultural context and the other the political system. Let us begin with the first one.

Initially meşk as an institution seemed to provide a kind of autonomy to musicians with respect to other social and political actors. At a closer look, however, we can easily show that the practice of messk is highly dependent on the broader social context because, for what Behar (1998) calls "messk-cycle" to continue, masters constantly need new students. Ottoman art music, therefore, could only survive as long as this music was valued in the society at large, making it attractive for new generations. In this respect, messk as an institution rendered Ottoman music highly sensitive, if not vulnerable, to changes in public taste and cultural attitudes.

This vulnerability was invisible as long as Ottoman art music remained a respected type of music in urban areas. Starting from the $18^{\text {th }}$ century onwards, however, there was a gradual shift in the cultural orientations of urban populations. Especially the members of "aristocratic" classes in Istanbul began to develop a growing fascination with European music and culture. This attitude would eventually spread to urban middle classes and, by the second half of the nineteenth century, Ottoman society was on its way to become considerably "Westernized." This also entailed that Ottoman art music was less and less valued by the Court. Many master musicians in the late nineteenth century were expressing their concerns about the diminishing respect for their art and the difficulty of finding new apprentices (Feldman, 1996:15-6; Cemil, 2002).

As O'Connell (2000) points out, art musicians responded to this situation by a variety of strategies. Some preferred to retreat and continue their traditional practice in Mevlevi houses. Others tried to adapt to the changes, by utilizing western notation and instructional techniques and even by composing in accordance with the popular taste. And, yet some others - including a number of Mevlevi musicians - attempted to use western techniques and notation to preserve the past repertory. The impact of this last group was particularly significant in terms of music education, since, between the years of 1914-1925, it led to the establishment of Darul'elhan, 
the first music conservatory in the Empire, where written transmission of music was particularly encouraged. ${ }^{26}$

Beyond these strategic responses to the changes in the cultural context, there was a second force that led to the adoption of notation by Ottoman/Turkish musicians, as the modernization process brought an end to the immunity of musical practices from state intervention. The first explicit intervention by state authorities on music education occurred in the military music school in 1826. This is not so surprising since military music was perhaps the only "politically" significant use of music in the Ottoman Empire (see: Deringil, 1993:9). The school went through a radical reform - which included the introduction of music notation - under the auspices of European musicians invited from abroad (Ayangil, 2008; Kösemihal, 1939: 98-101). The impact of this reform, however, was quite limited in comparison with the changes that would occur in the next century with the establishment of Turkish Republic (1923). As the Republican political authorities attempted to tailor a new music culture which would be suitable for the new - "modern" - Turkish national identity they sought to create, music became a deeply political matter. There ensued, in the decades to follow, a fierce debate between those who condemned traditional Ottoman music as "non-Turkish" and "obsolete," and those who claimed that it was an authentic product of Turkish culture (Ergur and Aydin, 2006; Feldman, 1990; Karakayali, 2001; O’Connell, 2000; Stokes, 1992). ${ }^{27}$ Music education became one of the major symbols and arenas of this struggle. As the proponents of modernization gained further ground, instruction based on notation became solidly institutionalized.

The particular historical circumstances in which music notation was adopted in twentieth-century Turkey, of course, was immensely different than the circumstances in Western Europe a millennium earlier. Yet, it can be argued that, in both cases, the social and political forces that supported the utilization of music notation had a striking similarity. In both cases, political actors were concerned about music to the extent that music played a role in the formation of a collective identity; in both cases, the adoption of music notation was partly enforced by political actors who were seeking ways to control music education with the aim of establishing a culturally and politically unified society.

\section{Conclusion: Power, Knowledge and Techniques of Cultural Transmission}

The contrasting attitudes towards music education and notation in Ottoman and European music history have already been discussed 
in many works. In this study, I tried to build on and synthesize the observations in the existing literature to develop a comparative sociological understanding of why methods of transmission and education in two music cultures diverged from each other in such significant ways. I was particularly interested in investigating in what ways political actors could influence the choices of musicians regarding the techniques used in education. In other words, my focus has been on the ways in which the relations between musicians, political actors and techniques of musical transmission were assembled in the two societies - which I refer to as assemblages of cultural transmission.

To summarize, my analysis indicates that the relationships between musicians and political actors evolved in very different ways in Ottoman and European societies due to a number of historically contingent factors. In Europe, given the collective and highly political nature of liturgical practices, the control and standardization of liturgical repertories remained a concern for both religious and earthly authorities, at least since the fourth century onwards. This concern, combined with the long-lasting project of cultural correction and unification through the help of written texts, was one salient motivation for the use of notation as an effective technique of cultural standardization, once such a technique became available. In the Ottoman society, however, music was seldom a significant part of orthodox religious rituals. Institutionalized control of musicians was not only practically difficult (due to the largely non-professional nature of music education) but there was also little, if any, incentive for either the earthly or religious powers to formalize music education. Nor, perhaps, the master musicians had any motivation to give up the oral tradition which gave them exclusive control over musical repertory. The result was the gradual crystallization of two different assemblages of musical transmission in Ottoman and European societies.

While this analysis may still be quite sketchy and cannot readily extend to other domains of culture, the above observations lend support to the idea that techniques of reproduction can have a political significance because they are essential mediators in the standardization of cultural practices and distribution of cultural capital. In the light of this preliminary analysis, I would like to offer two general hypotheses regarding the forms that the relations between political authorities, cultural actors and technological artifacts used in cultural transmission can take:

1. If the central authorities in a society want to standardize a culture in conjunction with their interests, they are likely to 
support the development of impersonal techniques of reproduction that are capable of stripping cultural practices from their local context. An assemblage of cultural transmission based on such techniques does not put an end to master-student relations, but the master is no longer the only access-route of the student to "cultural capital." This allows more autonomy for the individual musician but it also subjects him/her, to use Simmel's (1968) term, to an "objective" culture. Thus, although the students are now relatively less dependent on the master, they still have to conduct themselves according to a set of rather precise standards.

2. In contrast, if an elite group of cultural actors (e.g. master musicians) wish to preserve their monopoly over cultural capital, they are likely to resist the proliferation of indirect means of cultural transmission that might give seekers of knowledge and skills an easy access to that capital. In a system of cultural transmission based on oral methods such as meşk, knowledge always passes to the student from teachers, through a process of transmission that is highly ritualized and hierarchical. Access to knowledge and skills depends on personal contacts and local networks. At the same time, however, such an assemblage of cultural transmission cannot easily be standardized and centralized; it is quite immune to intervention and manipulation from outside, and allows for local variation.

These two hypotheses are far from providing a full-fledged theory about the interrelationships between politics and cultural transmission. Research in other music traditions and other domains of culture might well reveal connections and tendencies that are not observed in this study. Nevertheless, I hope the analysis provided here will be instrumental in motivating further inquiry into the reasons why technological artifacts are not accepted and utilized in the same way in different societies.

\section{Notes}

${ }^{1}$ One paradigmatic example of cross-cultural differences in the adoption of technologies used in cultural reproduction can be observed in the history of the printing press, the prototype of which was developed in China, but which found widespread use in Western Europe. Ottomans were introduced to this invention almost at the same time as Europeans, but they resisted its use for a considerably long time. See: Robinson (1993).

2 My use of the term, "assemblage," is partly inspired by the works of Latour (2005), Deleuze (2006), and Foucault (1977) who propose this concept as an alternative to essentialist and totalizing conceptions of social phenomena. My purpose here is more or less the same, as I use the term 
as an alternative to perspectives that explain technological change as a function of "culture" or vice versa. See: de Landa (2006).

${ }^{3}$ Here I use the term "art music" in a technical sense. It denotes a musical tradition where music is composed by individual composers in accordance with a theoretically elaborated system of rules.

${ }^{4}$ In principle, of course, techniques of musical transmission in any two traditions could have been compared in a study of this type. What reasons, then, do I have to focus on these two cases specifically - beyond, of course, obvious practical reasons such as my lack of knowledge about other music traditions? It is certainly not because I consider Ottomans and Europeans as representatives of the "East" and the "West." I cannot emphasize enough that the aim of this study is not to compare two cultures or "civilizations." In fact, from a methodological point of view, it is not so much the distance but the geographic proximity and the longlasting cultural transactions between these societies that make this comparison worthwhile. Ottoman musicians did not live in a radically different environment than their European counterparts - they lived in a script culture, wrote down the lyrics of their compositions, and were exposed to several notation systems including the European staff notation. It is precisely these similarities that allow us to assess the importance of sociological factors that lead to the divergence in the techniques of music education.

${ }^{5}$ For the sake of simplicity and convenience I often refer to "musicians" in Ottoman and European societies. But it should be rather obvious from the context that my reference is actually to very specific groups of musicians, namely, in Europe, practitioners of religious music, and in the Ottoman Empire, art musicians who were mostly located in Istanbul. Historically, in both societies, musicians in these groups were the most likely candidates to use notation in music education.

6 The political significance of technical media is discussed in many works. Benjamin's (1968) well-known essay on mechanical reproduction, for example, ultimately revolves around the question of the impact of the mechanically reproduced popular art products on the "political consciousness" of the masses, while Baudrillard's (1983) reflections on "simulation" announce the end of such mass politics. On a very different note, scholars dealing with modern nationalism often underline the role of the printing press in the standardization of national cultures (Anderson, 1983). Bourdieu's argument that structural, institutional and even spatial barriers to the distribution of cultural capital in a society can be instrumental in the reproduction of class distinctions might also be cited as a relevant example here (Bourdieu and Passeron, 1977). Paul Virilio's (1986) pioneering work on the significance of fast and accurate transmission of information for modern war and politics is yet another case in point. A key argument in Lyotard's (1984) work on postmodernism is that politics in the postmodern era will revolve around the question of access to information. Finally, recent research on the social consequences of the Internet point to changes in identity politics as a result of growing interaction between previously separated groups (Cerulo 1997; Chayko, 2002).

7 The intended audience of this article is sociologists interested in the interactions between technology, culture and politics. While the article might also be of interest to musicologists and historians of music, it is not primarily a musicological study and much of the musicological and historical data presented here is not new for experts in those fields. It is the 
reevaluation of this data from a comparative sociological perspective which constitutes the main contribution of this study.

8 It might seem odd that, in this section, I focus on quite different periods in Ottoman and Western European history. This is because I am not comparing two societies or cultures here, but two events (or processes). In the case of Europe my discussion refers mainly to the period between ninth and eleventh centuries, because this was the period in which the use of notation gained its first impetus. In the Ottoman case, the period discussed is (approximately) between the fifteenth and nineteenth centuries, i.e. the period in which art music practice flourished within a predominantly oral tradition.

9 At least three distinct systems of notation became available to Ottoman musicians in different periods of history. The first of these was the consonantal-alphabetical, "abjad" (in Turkish, "ebced") notation first developed by theorists and practitioners of Arabic and Persian music. This system was based on the letters of the Arabic script, where single or double letters represented tones and the numbers written below or above these letters indicated duration (Farmer, 1970). Versions of this system was used by a host of Arabic, Persian and Turkish musicians and theorists, including Abdulkadir Meragi who was well-known to Ottoman art musicians (Bardakci, 1986; Popescu-Judetz, 1996). Demetrius Cantemir (in Turkish, Kantemiroğlu), the Prince of Moldavia, who spent many years in Istanbul at the turn of the $18^{\text {th }}$ century, wrote a theoretical treatise and compiled a collection of the Ottoman repertory available in his time, using a modified version of this system (Wright, 1992). Cantemir's contemporary, the Mevlevite musician Osman Nayi Dede also produced a collection using a strikingly similar notation system - it is not known whether the two musicians were in contact while developing their systems. Later, with some revisions and additions, Cantemir's collection and system of notation was replicated by a number of Ottoman art musicians, including Mustafa Kevseri (Popescu-Judetz, 1998). At least by the middle of the seventeenth century, a number of Court musicians were also introduced to European staff notation through Bobowski (of Polish origin) who was brought to Istanbul as a war captive, served as a court musician for 20 years and adopted the name Ali Ufki (Behar, 1990; Feldman, 1996). Ali Ufki also compiled a collection of the Ottoman repertory in staff notation. Finally, beginning with the mid-eighteenth century onwards, we see the emergence "hybrid" systems, resulting from the long-lasting cross-cultural transactions between Turkish, Greek and Armenian music traditions, which, in a sense, are the most uniquely Ottoman forms of notation. One of the first examples of such systems, which mixes neumatic and alphabetic elements, can be found in the eighteenth-century treatise of Ottoman Armenian musician Tanburi Küçük Artin (Popescu-Judetz, 2002). A more important example is the Hamparsum notation developed by another Ottoman Armenian musician Hampartsoum Limondjian (1769-1839), which was widely used by art musicians in nineteenth-century Istanbul but gradually fell out of use with the adoption of European notation in the twentieth century (Kösemihal, 1939:96). For a full overview of notational systems used by Ottoman musicians, see: Popescu-Judetz (1996).

${ }_{10}$ As mentioned in the previous footnote, these musicians include, among others, Osman Nayi Dede, Mustafa Kevseri, Tanburi Küçük Artin and Hampartsoum Limondjian. See: Feldman (1996:25, 31-2) and Popescu-Judetz (1996:30-43). 
${ }^{11}$ Whether the fact that these musicians were partly perceived as "strangers" might have influenced the attitudes of "native" musicians might be worth inquiring further. See: Karakayali $(2006,2009)$.

${ }^{12}$ Let us note that professional court musicians in the Ottoman Empire constituted a minority, and most urban art musicians were essentially amateurs, who made their living from other activities (Behar, 1998).

${ }^{13}$ Later, similar theoretical works were also written by Ottoman theorists and a similar system of notation was also used by Ottoman musicians. See, for example, Ertan (2007).

${ }^{14}$ A full discussion of the technical details of Guido's system is beyond the scope of this paper. See: Smits van Waesberghe (1951).

15 The development of music notation and educational techniques in Europe indicates a "continuum" between oral and written transmission practices. In fact, many musicologists today refuse to posit a clear-cut distinction between oral and written transmission. This critique of "oralityliteracy" dichotomy ranges from Feld's (1986) questioning of the thesis that orality and literacy can be conceptualized as two basic communication codes that are capable of structuring people's perception of reality independent of ecological and historical factors, to the realization that, in many cultures, the two often constitute overlapping practices in a "historical continuum," such that it is best to think of the relation as "a gradual shift from the predominance of one kind of transmission to the predominance of the other, a shift that can be seen to have happened in stages." (Jeffery, 1992:63).

${ }^{16}$ Let us note in passing that the value placed on genealogical links between masters and students did not mean that oral transmission excluded the possibility of innovation and change over generations - a point observed by scholars of both Ottoman and pre-notation European music. However, while oral transmission has much room for creativity, it always situates the reproducing actor in a social and cultural context which sets limits to the extent to which this actor can experiment with the "original" material. As Helmut Hucke puts it, "in performing a gradual verse a cantor had a general pattern to follow, and certain rules to observe with respect to the text [i.e. "lyrics"]. But there were opportunities for him to demonstrate his artistry in the way that he accommodated each individual text to the general pattern." (Hucke, 1980:460; cited in Jeffery, 1992:16).

17 Many contemporary musicologists and sociologists also dwell upon the potential of writing and other new technical media in facilitating a de-personalized and de-contextualized transmission process, but they do so in a more critical manner than Guido. See, for example: Wishart (1996), Shepherd et al. (1980), Benjamin (1968), Baudrillard (1983).

${ }^{18}$ In this sense, music notation too presupposes the development of bodily skills through its essential association with sight-reading which, as some researchers have pointed out, "is a complex transcription task involving a series of overlapping perceptual, cognitive, and motoric processes" (Kopiez and Lee, 2008:42). Sight-reading too, in other words, requires the development of bodily habits, but only in the sense of mastering a general technique necessary for reading scores.

19 There are several different views in the literature about whether the term "notas" here is used in the sense of music notation or something entirely different. For a brief review of these views, see: Atkinson (2009:49, fn.3). 
${ }^{20}$ For a list of the major works on this topic, see: Levy (2003:6, fn.3). Note, however, that in this article, Levy suggests that "Roman" and "Gregorian" repertories were not identical.

${ }^{21}$ In fact, Levy (1987) suggests that a partly notated - "neumed" version of the Gregorian repertory might already be in existence in Charlemagne's time. For criticisms and an alternative view, see: Hornby (2004).

22 In his critique of Max Weber's sociology of music, Turley (2001: 640-2) notes that much of Weber's analysis - and in fact much of the later histories of Western music - is based on Roman Catholic Church documents, which might make the contribution of "lower status" musicians rather invisible. However, as he also seems to recognize, the Church was probably the only agent in that period with enough power to impose and encourage the use of music notation in such a colossal scale (Turley, 2001:642).

${ }^{23}$ One of the earliest cases of musical ban in the Empire is reported to have occurred in the sixteenth century, during the rule of Süleyman (the Magnificent), under heavy pressure from religious authorities (Aksoy, 1994:44-6). Activities of court musicians came to a halt for two decades, also during the rule of Osman III and his successor, Mustafa III, between 1754-1774 (Behar, 1992:28).

${ }^{24}$ As in the case of some poets (Inalcik, 2003; Andrews, 1985), a select few of these musicians might gain the patronage of the Sultans, which might entail full-time professional employment, and perhaps also other economic benefits. However, gaining the patronage of elite groups was often dependent on building up a reputation in the larger community of musicians.

25 As Behar (1998:65) has acutely observed, it might not be a coincidence that in the nineteenth century when private teachers began to offer "paid" music lessons, they also started to use notation in their classes. The moment, in other words, teacher-student relations took on an instrumental and contractual form through the medium of money was also the moment when notation could slip into music education.

${ }^{26}$ This sudden introduction of notation to Ottoman art music, however, was not without problems. Reformist musicians tried to adopt Western notation which was not always fully adequate for representing the intricate intervals and rules of performance of makam music. Disagreements about how to notate makam music properly still continue today (Ayangil, 2008).

27 Turkey, of course, was not the only country in which such debates and struggles occurred with the emergence of a modern nation state. See, for example, Rice (1994).

\section{References}

Aksoy, Bülent. 1994. Avrupalı Gezginlerin Gözüyle Osmanlılarda Musiki [Ottoman Music through the Eyes of European Travelers]. Istanbul: Pan.

Anderson, Benedict. 1983. Imagined Communities: Reflections on the Origin and Spread of Nationalism. London: Verso.

Andrews, Walter. 1985. Poetry's Voice, Society's Song: Ottoman Lyric Poetry. Seattle: University of Washington Press.

Atkinson, Charles M. 2009. The Critical Nexus: Tone-System, Mode and Notation in Early Medieval Music. Oxford: Oxford University Press.

Ayangil, Ruhi. 2008. "Western Notation in Turkish Music." Journal of the Royal Asiatic Society, 18(4): 401-447. 
Bardakçı, Murat. 1986. Maragalı Abdülkadir. Istanbul: Pan.

Baudrillard, J. 1983. Simulacra and Simulations. New York: Semiotext(e).

Behar, Cem. 1987. Klasik Türk Musikisi Üzerine Denemeler [Essays on Turkish Classical Music]. Istanbul: Bağlam Yay.

Behar, Cem 1990. Ali Ufki ve Mezmurlar [Ali Ufki and the Psalms]. Istanbul: Pan.

Behar, Cem 1992. Zaman, Mekan, Müzik [Time, Space, Music]. Istanbul: AFA.

Behar, Cem. 1998. Aşk Olmayınca Meşk Olmaz. Geleneksel Osmanlı/Türk Müziğinde Öğretim ve İntikal [Without Love, There is no Meşk. Education and Transmission in Traditional Ottoman/Turkish Music]. Istanbul: YKY.

Benjamin, W. 1968. "The Work of Art in the Age of Mechanical Reproduction.” Pp. 217-252 in Illuminations, New York: Shocken Books.

Cemil, Mes'ud. 2002. Tanburi Cemil'in Hayatı [The Life of Cemil the Tanburist]. Istanbul: Kubbealti.

Ian D. Bent, et al. 2009. "Notation." In Grove Music Online. Oxford Music Online, http://www.oxfordmusiconline.com/subscriber/article/grove/ music/201 14pg4 (accessed April 13, 2009).

Bourdieu, P. 1990. "Social Space and Symbolic Power." Pp. 122-139 in In Other Words: Essays Towards a Reflexive Sociology, Stanford, CA: Stanford University Press.

Bourdieu, P. and J.C. Passeron. 1977. Reproduction in Education, Society and Culture. London: Sage Publications.

Boynton, Susan. 2003. "Orality, Literacy and the Early Notation of the Office Hymns." Journal of the American Musicological Society, 56(1): 99-168.

Boynton, Susan. 2006. Shaping a Monastic Identity: Liturgy and History at the Imperial Abbey of Farfa, 1000-1125. Ithaca, NY: Cornell University Press.

Busse-Berger Anna Maria. 2005. Medieval Music and the Art of Memory. Los Angeles, CA: University of California Press.

Caksu, Ali (ed.) 2001. International Congress on Learning and Education in the Ottoman World, Istanbul, 12-15 April 1999: Proceedings. Istanbul: Research Centre for Islamic History, Art and Culture.

Cattin, G. 1984. Music of the Middle Ages. vol. I. Cambridge: Cambridge University Press.

Cerulo, K. A. 1997. "Reframing Social Concepts for a Brave New (Virtual) World." Sociological Inquiry, 67(1): 48-58.

Chayko M. 2002. Connecting: How We Form Social Bonds and Communities in the Internet Age. Albany: SUNY Press.

Cole, Hugo. 1974. Sounds and Signs. Aspects of Musical Notation. London: Oxford University Press.

Cowdrey, H.E.J. 1998. Pope Gregory VII. Oxford: Oxford University Press.

de Landa, Manuel. 2006. A New Philosophy of Society: Assemblage Theory and Social Complexity. New York: Continuum.

Deleuze, Gilles. 2006. Two Regimes of Madness: Texts and Interviews 1975-1995. Cambridge, MA: MIT Press.

Denny, Walter. 1985. "Music and Musicians in Islamic Art." Asian Music, 17(1): 37-68.

Deringil, Selim. 1993. "The Invention of Tradition as Public Image in the Late Ottoman Empire, 1808 to 1908." Comparative Studies in Society and History, 35(1): 3-29. 
Ergur, Ali and Yigit Aydin. 2006. "Patterns of Modernization in Turkish Music as Indicators of a Changing Society." Musicae Scientiae, Special Issue: 2005/06: 89-108.

Ertan, Deniz. 2007. "Cycles and Peripheries: An Ottoman Kitâb el-Edvâr." Asian Music, 38(1): 31-60.

Farmer, H. George. 1970. Historical Facts for the Arabian Musical Influence. Hildesheim: Georg Olms Verlag

Feld, Steven. 1986. "Orality and Consciousness." Pp. 18-28 in The Oral and the Literate in Music, Tokumaru Yosihiko and Yamaguti Osamu (eds.), Tokyo: Academia Music.

Feldman, Walter. 1990. "Cultural Authority and Authenticity in the Turkish Repertoire." Asian Music, 22(1): 73-111.

Feldman, Walter. 1996. Music of the Ottoman Court: Makam, Composition and the Early Ottoman Instrumental Repertoire. Berlin: VWB-Verlag.

Foucault, Michel. 1977. Discipline and Punish: The Birth of the Prison. New York: Pantheon.

Fouracre, Paul. 2007. "Space, Culture and Kingdoms in Early Medieval Europe." Pp. 366-380 in The Medieval World, Janet Nelson (ed.), London: Routledge.

Goody, Jack. 1977. The Domestication of the Savage Mind. Cambridge: Cambridge University Press.

Gölpınarlı, Abdülbaki. 1953. Mevlana'dan Sonra Mevlevilik [Mevlevism after Mevlana]. Istanbul: Inkilap.

Guido of Arezzo. 1965. "Prologus antiphonarii sui." Pp. 117-120 in Source Readings in Music History: Antiquity and the Middle Ages, Oliver Strunk (ed.), New York: W.W. Norton and Company.

Hornby, Emma. 2004. "The Transmission of Western Chant in the 8th and 9th Centuries: Evaluating Kenneth Levy's Reading of the Evidence." The Journal of Musicology, 21(3), pp. 418-457.

Hucke, Helmut. 1980. "Toward a New Historical View of Gregorian Chant." Journal of the American Musicological Society, 33: 437-467.

Ihsanoglu, Ekmeleddin (ed). 1992. Transfer of Modern Science \& Technology to the Muslim World. Istanbul: Research Centre for Islamic History, Art, and Culture.

İnal, İbnülemin Mahmud Kemal. 1955. Son Hattatlar [The Last Calligraphers]. Istanbul: Maarif Basimevi.

Inalcık, Halil. 2003. Şair ve Patron: Patrimonyal Devlet ve Sanat Üzerine Sosyolojik Bir Inceleme [The Poet and the Patron: A Sociological Inquiry on Patrimonial State and Art]. Ankara: Dogu Batı.

Jeffery, Peter. 1992. Re-envisioning Past Musical Cultures: Ethnomusicology in the Study of Gregorian Chant. Chicago: University of Chicago Press.

Karakayali, Nedim. 2001. "An Introduction to the History of Music Debates in Turkey." Pp.125-136 in Sufism, Music and Society in Turkey and the Middle East, Hammarlund, Olson and Ozdalga (eds.), Istanbul: Swedish Research Institute.

Karakayali, Nedim. 2006. "The Uses of the Stranger: Circulation, Arbitration, Secrecy and Dirt." Sociological Theory, 24 (4): 312-330.

Karakayali, Nedim. 2009. "Social Distance and Affective Orientations." Sociological Forum, 23(3): 538-562.

Kopiez, Reinhard and Ji In Lee. 2008. "Towards a general model of skills involved in sight reading music." Music Education Research, 10(1): 41-62. 
Kösemihal, Mahmut Ragıp. 1939. Türkiye - Avrupa Musiki Münasebetleri [Musical Relations Between Turkey and Europe]. Istanbul: Numune Matbaasi.

Latour, Bruno. 2005. Reassembling the Social: An Introduction to the ActorNetwork Theory. Oxford: Oxford University Press.

Levy, Kenneth. 1987. "Charlemagne's Archetype of Gregorian Chant." Journal of the American Musicological Society, 40(1): 1-30.

Levy, Kenneth. 2003. "Gregorian Chant and the Romans," Journal of the American Musicological Society, 56(1): 5-41.

Luhmann, Niklas. 1995. Social Systems. Stanford, CA: Stanford University Press.

Lyotard, Jean-Francois. 1984. The Postmodern Condition: A Report on Knowledge. Manchester: Manchester University Press.

Mauss, Marcel. 1954. The Gift: Forms and Functions of Exchange in Archaic Societies. London: Cohen and West.

McKitterick, Rosamond. 2008. Charlemagne: The Formation of a European Identity. Cambridge, UK: Cambridge University Press.

Nelson, Janet L. 2007. "Medieval Monasticism." Pp. 576-604 in The Medieval World, Janet Nelson (ed.), London: Routledge.

O'Connell, J. Morgan. 2000. "Fine Art, Fine Music: Controlling Turkish Taste at the Fine Arts Academy in 1926." Yearbook for Traditional Music, 32:117-142.

Popescu-Judetz, Eugenia. 1996. Meanings in Turkish Musical Culture. Istanbul: Pan.

Popescu-Judetz, Eugenia. 1998. Kevseri Mecmuası [Music Collection of Kevseri]. Istanbul: Pan.

Popescu-Judetz, Eugenia. 2002. Tanburi Küçük Artin: A Musical Treatise of the Eighteenth Century. Istanbul: Pan.

Parrish, C. 1957. The Notation of Medieval Music. New York: Norton.

Rice, Timothy. 1994. May It Fill Your Soul: Experiencing Bulgarian Music. Chicago: The University of Chicago Music.

Robinson, Francis. 1993. "Technology and Religious Change: Islam and the Impact of Print." Modern Asian Studies, 27(1): 229-251.

Rockstro, W. S. 1889. "The Great Musical Reformers: II. Guido d'Arezzo." The Musical Times and Singing Class Circular, 30(552): 7578.

Rubin, David. 1995. Memory in Oral Traditions: The Cognitive Psychology of Epic, Ballads, and Counting-out Rhymes. New York: Oxford University Press.

Schimmel, Annemarie. 1990. Calligraphy and Islamic Culture. London: I.B.Taurus and Co. Ltd.

Shehadi, Fadlou. 1995. Philosophies of Music in Medieval Islam. Leiden: E.J.Brill.

Shepherd, John and P. Virden, G. Vulliamy, T. Wishart. 1980. Whose Music? A Sociology of Musical Languages. New Brunswick, N.J.: Transaction Books.

Shiloah, Amnon. 1995. Music in the World of Islam. A Socio-Cultural Study. Detroit: Wayne State University Press.

Simmel, G. 1968. The Conflict in Modern Culture and Other Essays. New York: Teacher's College Press.

Sinding-Larsen, H. 1991. "Computers, Musical Notation, and the Externalisation of Knowledge: Towards a Comparative Study in the History of Information Technology." Pp. 101-126 in Understanding the Artificial: 
On the Future Shape of Artificial Intelligence, M. Negrotti (ed.), London: Springer.

Smits van Waesberghe, Joseph. 1951. "The musical notation of Guido of Arezzo." Musica Disciplina, V: 15-53.

Stokes, Martin. 1992. "Islam, the Turkish State and Arabesk." Popular Music, 11(2): 213-227.

Sullivan, Richard E. (ed.) 1995. "The Gentle Voices of Teachers": Aspects of Learning in the Carolingian Age. Columbus, OH: Ohio State University Press.

Treitler, Leo. 1974. "Homer and Gregory: The Transmission of Epic Poetry and Plainchant." Musical Quarterly, 60: 333-372.

Trimingham, J. Spencer 1971. The Sufi Orders in Islam. London: Oxford University Press.

Turley, Alan C. 2001. "Max Weber and the Sociology of Music." Sociological Forum, 16(4): 633-653.

Uzunçarşılı, I. Hakkı. 1977. Osmanlılar Zamanında Saraylarda Müzik Hayatı [Musical Life in Ottoman Courts]. Ankara: TTK.

Virilio, Paul. 1986. Speed and Politics: An Essay on Dromology. New York: Semiotext(e).

Weber, Max. 1958. The Rational and Social Foundations of Music. Carbondale, Ill.: Southern Illinois University Press.

Wishart, Trevor. 1996. On Sonic Art. Amsterdam: Harwood Academic Publishers.

Wright, O. (ed). 1992. Demetrius Cantemir: The Collection of Notations. Part I: Text. London: SOAS Musicology Series. 